\title{
CHEMICAL COMPOSITION OF THE ZOOPLANKTON COMMUNITY SUBJECTED TO LANDBASED ACTIVITIES ALONG ALEXANDRIA COASTAL WATERS
}

\author{
Mohamed A. Abdet-Moudind Nethad M. Nour TL-DM \\ Oceanography Deparment. Facully of Science. Alexandriat \\ University, Moharam Bey 21511 , Alxandria. Fe?
}

Keywords: 7ooplankton, chemical composition coastal polludidat.

Nexandria

\section{ABSTRACI}

$\mathbf{T}$ he chemical composition of zooplankion has been stadicd during $1999 / 2000$ along the coustal waters of Alexandria from 8 stations representing different areas subjected to different types and quantities of landbased activities. The annual averages of carbon. nitrogen and phosphorus contents during the period of study were $45.30 .5 .84^{\circ}, 6$ and $0.42 \%$, respectively. The N:P ratio for zooplankwon was 13.9 while that of $\mathrm{C}: \mathrm{N}$ ratio was. 7.75 , i. eremarkably higher than that reported for marine organisms. Organisms collected opposite to sewage discharge were characterized by high chemical components while opposite to industrial discharge, the zooplankton chemical components were minimum. The chemical composition of zooplankton is mostly affected by the variations of available food represented by chlorophyll a concentrations.

\section{INTRODUCTION}

Plankton is a useful tool for monitoring certain aspects of the environment such as hydrographic events, eutrophication, pollution and long term changes in the environmental conditions. Marked abnormalities of species composition may indicate the need for more intensive physical and chemical analysis.

The increasing importance of the biogeochemical cycles of elements have stimulated several researchers to study the chemical composition of plankton community in order to evaluate its role in these cycles. Beers (1966) studied the total carbon and chemical composition content of plankton. For the N.W. Mediterranean Sea Hardstedt-Romen (1982) presented the concentration of carbon. 
nitrogen and phosphorus as well as other melals in ratural populations of zooplankton.

The chemical composition of the zooplankton communit! varies within a certain range, depending mainly on envirnmontal lactors. The increase or decrease in the chemical parancers of an organiom is dependent on some lactors such as the antplitude of annual discharge from landbased sources, availability of ford as well as some physical parancters like temperature and light

Since zooplankton is considered the main food source for the marine fishes along the coistal waters of Alexandria and in vien of the variations in ypes and amounts of discharged pollutants. the present work was attempted to evaluate the changes in the chemical composition of gopplanklon conmumity in vew of changes in water quality variables

\section{MATERIAL AND METHODS}

\section{STUDY AREA:}

The investigated area extends along the coast of Alexandria between Mex area in the west and Abu-Qir Bay (Boughaz. El-Madia) in the east (Figure 1). Mex Bay (stations 1 and 2), receives wastewater from several effluent sources. ex: Ummum agricultural drain $\left(6 \times 10^{6} \mathrm{~m}^{3} / \mathrm{d}\right)$, as well as water from the Western Harbor $(3.1 \mathrm{x}$ $10^{6} \mathrm{~m}^{3} / \mathrm{d}$ ). Qayet Bey area (stations 3 and 4) is located west to the Fastern Harbor of Alexandria. The area receives from Qayet Bey Pump Station (QBPS) about $150-200 \times 10^{3} \mathrm{~m}^{3} / \mathrm{d}$ of untreated sewage from the main metropolitan sewage station of the central part of Alexandria discharging through a pipeline extending about $760 \mathrm{~m}$ offshore at $4 \mathrm{~m}$ depth west of the harbor opening (Fig. 1). Abu Qir (AQ) Bay, where stations 5 and 6 (Tabia sector) and 7 and 8 (Maadia sector) were sampled, is located at the eastern part of Alexandria and bordered from the eastern side by Rosetta estuary. The bay receives $0.73 \times 10^{9} \mathrm{~m}^{3} / \mathrm{y}$ of industrial discharge of 36 factories including paper mills, chemicals, dyes, textiles, fertilizers...etc., through Tabia pump station and about $1.4 \times 10^{9} \mathrm{~m}^{3} / \mathrm{y}$ of brackish agricultural water from Lake Fdku.

During summer (July, 1999) and winter (February, 2000), zooplankton samples were collected from 8 stations, using a zooplankton net of $1 \mathrm{~m}$ mouth diameter and $120 \mu \mathrm{m}$ mesh size. An additional station (st. A) not subjected to any landbased activities was sampled west to Nlexandria and treated as control Th. net was tomed 
horizontally for about 20 minutes at the lowest ship speed (about $0.25 \mathrm{~m} / \mathrm{s}$ ). Samples were preserved into $250 \mathrm{ml}$ glass containers previously soaked in $3 \mathrm{M}$ pure $\mathrm{HCl}$. washed with double deionized distilled water and rinsed with filtered sea water before sampling. Samples were kept in an ice bux and deep frozon at $20^{\circ} \mathrm{C}$. The whole horizontal haul simples were placed in a Petridish micosenpically examined and the rooplankion population was identified

Samples were dried in an oven at $65^{\circ} \mathrm{C}$ until con tital seight and sored in glass scintillation rials. Dried amplos were stand in a desiccator. with silica gel as desiccant, for subequent analyses. All weighings for chemical analy sis were performed at accuracy of $5 \times 10^{-1}$ and sensitivity and readability of $0.1 \mu \mathrm{g}$.

Carbon and nitrogen conentrations rere detcmined wing Model 1104 Carla Liba demental analyer. whts Acctuntide as

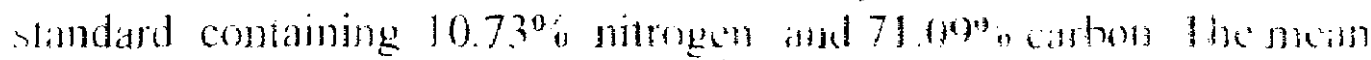
relative crors for duplicate dekminations of standard were $+7^{\circ} \%$ carbon and $5^{\circ}$. nitrogen.

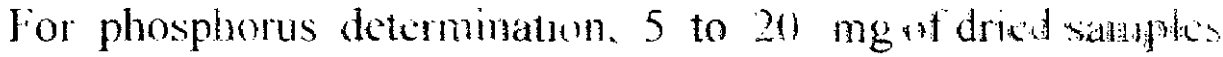
were mixed with $\mathrm{NaOH}$ and dissolved with conc. 14C1. Phosphorts was analyzed using the molybdate method (Murphy and Riley, 1962).

Simultaneously during the study period, water samples from the same stations were collected for temperature, dissolved oxygen. secchi disc and salinity measurements as well as the analyses of chlorophyll a biomass, reactive phosphorus and nitrate-nitrogen (Strickland and Parsons. 1972).

\section{RESULTS AND DISCUSSION}

The zooplankton community along the coastal waters of Alevandria is dominated by Copepoda $(68 \%)$ followed by (haetognatha $(8.3 \%)$. Polychaete larvae $(6.0 \%)$. Mollusc veliger $\left(5.4^{\circ} \%\right)$ and Appendicularia $\left.3.2 \%\right)$.

\section{Carbon content:}

The carbon content (as percentage of dry weight) of zooplankton showed not only variations between the different localities, but also within the different sampling sites of the same area (Fig. 2). In Abu Qir Bay, the lowest carbon content of zooplankton (32.4\%) was generally observed during summer at the inshore site opnosite to El-Tabia pump station (TPS) discharging industrial wastewater (St. 5). The dissolved oxygen content at this station was 
extremely low $(<2.5 \mathrm{ml} / 1$.) However, during winter, the carbon content at this location was $38.3 \%$. The maximum carbon content observed for El-Tabia sector reached $50.6 \%$ at the offshore location (St. 6) during winter.

On the other hand, the carbon content of zooplankton off Boughaz El-Maadia (St. 7), affected by agricultural discharge, varied over the same magnitude like those of El-Tabia i.e. between $35.3 \%$ in summer and $41.7 \%$ in winter. Similarly, the carbon content of ElMaadia area increased gradually offshore at St. 8 (range $43.0 \%$ $53.1 \%$ ), far from the discharge point (Fig. 2).

The carbon content of zooplankton off QBPS (Sts. 3 and 4) (Fig. 2) was significantly higher than those recorded for Abu Qir Bay. Zooplankton carbon was characteristically high offshore QBPS (St. 4) reaching 63.2\% during summer (Fig. 2). The station directly affected by sewage discharge (St. 3) showed remarkably low carbon contents $42.5 \%$ and $44.6 \%$ during summer and winter, respectively.

Opposite to the discharge point, the carbon content of the Mex Bay samples fluctuated between $32.1 \%$ and $38.0 \%$ in winter and summer, respectively. On the other hand, despite the relative oligotrophic nature of st. A sampled at the western coast, the average carbon content of zooplankton was $54.0 \%$. Generally, seasonal variations in sampling sites were related principally to the seasonal amplitudes in the discharge from landbased sources as well as its reflection on the productivity and biomass of phytoplankton in the different localities. Coastal stations that are highly affected by either industrial or agricultural discharge indicated by low salinity values reaching 22.3 psu at El-Maadia opening in winter showed low carbon contents. Industrial disposal containing toxic chemicals and showing low $\mathrm{pH}$ (6.8-7.5) seemed to have a higher impact on lowering the carbon content.

On the other hand, the chlorophyll a off QBPS (av. $6.63 \mathrm{mg}$ $\mathrm{chl} \mathrm{a}^{\prime} \mathrm{m}^{3}$ ) corresponds to the maximum carbon content of the organisms for locations subjected to land discharge. Correlation between the carbon content and chlorophyll a in this area was statistically significant $(\mathrm{r}=0.8319, \mathrm{p}<0.001)$ indicating the importance of food supply in building up the carbon content of organisms.

Curl (1962) reported 29.8\% dry weight carbon in samples of mixed copepods and phytoplankton with an average of $38.3 \%$ carbon in crustaceans. Among 4 copepod species from the N.W. Mediterrancan. (hampalhen and kerambrun 1978 , Cumb antom 
ranging from $32.4 \%$ to $43.3 \%$. Hardstedt-Romeo (1982) observed high carbon values $(48 \%)$ in plankton samples from the NW Mediterranean.

The present investigation revealed an average carbon for zooplankton of $45.3 \%$ of dry weight which is accepted for inshore tropical species and considered within the range recorded by most investigators.

Using carbon leveis, Kerambrun (1978) calculated energy equivalents to range from 4.28 to $5.00 \mathrm{cal} / \mathrm{mg}$ DW. Applying his conversion factor for zooplankton, the organism could have an average energy equivalent of $5.9 \mathrm{cal} / \mathrm{mg}$ dry weight. On the other hand, Calanus finmarchicus has equivalent energy values of 5.23210 $7.672 \mathrm{~K}$ cal /g DW (Comita and Schindler, 1963; Comira et al., 1966). Moreover, for different stages of Centropages typicus and Temora stylifera high calorific values were obtained, reaching 6 to 7 $\mathrm{cal} / \mathrm{mg} \mathrm{DW}$.

\section{Nitrogen content:}

Zooplankton from the coastal waters of Alexandria sustained an average nitrogen level of $5.84 \%$, which is at least one order magnitude lower than those recorded in other localities. The nitrogen content of zooplankton covered the range between $1.6 \%$ and $11.3 \%$. Such wide variation reflects the effect of landbased sources on the body contents of the organisms sampled opposite to the effluents. The lowest value i.e. 1.6\% was observed opposite of El-Tabia pumps in summer (Fig. 2). However, this season was characterized with a common low nitrogen content in all sampled areas.

The offshore station of QBPS generally recorded the highest values especially in summer (absolute maximum). Similar to Abu Qir Bay, the nitrogen levels of zooplankton increased seaward in Mex Bay, as the organism is apart from the direct discharge of industrial wastes, reaching $4.6 \%$ in winter (Figure 2 ). The highest value for the study area was recorded for the western station (Agami) $(8.8 \%)$ observed during winter 2000 . Beers (1966) observed $9.62 \% \mathrm{~N}$ (dry weight) in copepods and $7.83 \% \mathrm{~N}$ in other crustaceans from samples collected from the Sargasso Sea. Among 4 species of copepods from the NW Mediterranean, Champalbert and Kerambrun (1978) found nitrogen concentrations ranging from $9.3 \% \mathrm{~N}$ and $11.5 \% \mathrm{~N}$. For Pontella mediterranea, Champalbert and Kemambrun (1979) reported an average nitrogen content of $11.4 \%$. Williams and Robin (1982) measured nitrogen in Calanus helgolandicus collected from 
the Cetlic Sea and observed levels around $10.89 \pm 0.73 \%, 10.36$ $\pm 1.5 \%$ and $9.28 \pm 1.61 \%$ for fresh, frozen and fixed specimens, rispectively.

The nitrogen content of QBPS zooplankton is highly related to the chlorophyll a biomass off the discharge, showing strong coincident peaks $(r=0.7316, p<0.001)$. For other regions, a negative correlation was observed between chlorophyll a content (available food) and the nitrogen content of zooplankton ( $\mathrm{r}=-0.6150, \mathrm{p}<0.01$ during winter and $r=-0.2273, p<0.05$ during summer). A negative corrclation also appeared between the nitrogen content of zooplankton and nitrate content of water $(r=-0.5201, p<0.01)$ indicating the use of nitrate for zooplankton body nitrogen synthesis Ammonia, which was not measured by that time could also be an additional and/or substitutional source for nitrogen. When nitrogen sufficient media prevail, indicated from the concentrations in water. the organism contained a consistent amount of nitrogen. However. organisms could suffer nitrogen starvation with a total decrease in cellular nitrogen, internal decrease of $\mathrm{NO}_{3}$ and amino acids followed by a drastic reduction of protein and $\mathrm{NO}_{3}$ normally used to sustain growth when nitrogen source is depleted, constituting the nitrogen store when $\mathrm{N}$ is plentiful (Dortch, 1982).

\section{Phosphorus content:}

The annual average concentration of phosphorus content for zooplankton collected from the coastal waters of Alexandria was $0.42 \%$. A minimum value was recorded in summer at st. $5(0.1 \%)$ opposite to the industrial outfall in Abu Qir Bay (Figure 2). During summer and winter the highest average values were recorded offshore QBPS $(0.76 \%$ and $0.89 \%)$. During summer, nearly similar values were noticed at station $\mathrm{A}(0.41 \%)$ and El-Maadia sector of AQ $(0.41 \%)$. A high phosphorus percentage was recorded at st. A $(0.52 \%)$ during winter.

It seems likely that the phosphorus content of zooplankton is slightly affected by reactive phosphorus concentration in water. Generally, zooplankton collected from stations affected by direct discharge of industrial wastes showed remarkably low phosphorus cortents especially at times of high discharge periods. However, the discharge of agricultural runoff from Lake Edku through Boughaz ElMaadia enriched with reactive phosphorus during winter i.e. $1.9 \mu \mathrm{M}$ lead to a corresponding elevation in the phosphorus levels in zooplankton during this season $(0.53 \%)$. Apart from the direct discharge, sewage disposal through QBPS seems gencrally to 
increase phosphorus levels in the organisms. In spite of this. maximum discharge periods are not accompanied by high $P$ contents probably because most of the $\mathrm{P}$ is discharged in the organic form (Aboul-Kassim, 1987). This relationship between reactive phosphorus and zooplankton phosphorus, though not highly significant. was negative for both seasons $(r=-0.382, p<0.01)$.

Similar to nitrogen, zooplankton use phosphorus in water through phytoplankton uptake to biuld body phosphorus, though still other sources like Dissolved Organic Phosphorus (DOP) could be of considerable importance. DOP in the coastal waters of Alexandria constituted between 20 and 65\% (Aboul-Kassim, 1987). However. the phosphorus content of water is not only a factor of discharge but also of the amount of chlorophyll a (chosen as a phytoplankton biomass indicator) concentration.

Z.ooplankton sampled at st. A located west to Alexundria, was characterized by low phosphorus content especially during summer $(0.29 \%)$. Reactive phosphorus levels in this station were extremely low (range $0.05-0.16 \mu \mathrm{M}$ ). On the other hand, a significantly positive relation $(\mathrm{r}=0.9525, \mathrm{p}<0.01)$ appeared between the phosphorus content of the zooplankton and chlorophyll a biomass in water. This condition indicates that despite the low phosphorus content of water, phytoplankton can assimilate these low concentrations, forming a phosphorus rich diet to zooplankton.

Beers (1966) in the Sargasso Sea, reported higher levels of phosphorus for copepods $(0.79 \%)$, for Euphausiacea $(1.48 \%)$ and for other Crustacea $(1.26 \%)$. In the Liguro-Provencal basin, HardstedtRomeo (1982) recorded an average of $0.79 \pm 0.11$ for the total zooplankton population; while. for the southern French coast, he observed low phosphorus content in nearshore planktonic samples. which were mainly composed of phytoplankton and a relatively higher content of copepods and other crustaceans.

\section{$C: N, C: P$ and $N: P$ ratios in zooplankton:}

$\mathrm{C}$ and $\mathrm{N}$ proportionate levels reflect food quantity, production cycles and trophic level (lkeda, 1974). Their ratio is explained as a measure of organisms' condition, because of their relation to lipid and protein (Conover and Comer, 1968).During the present study, the $\mathrm{C}: \mathrm{N}$ ratio of zooplankton showed insignificant differences between summer 7.72 and winter 7.77. Higher $\mathrm{C}: \mathrm{N}$ ratios followed phytoplankton blooms, while lower averages were observed before the bloom. In the Sargasso Sea, C:N ratio for copepods ranged from 5.0 to 3.8 (Beers. 1966). In contrast. Omori (1969) observed a low 
ratio i.e. 2.6-3.2 throughout the year, because of the uniformity of the environment. Recorded $\mathrm{C}: \mathrm{N}$ ratio for Acartia clausi collected from different areas near Marseille (Kerambrun, 1978) fluctuated from 3.22 to 3.80 with minimum values in summer and highest in winter. For the copepod Euterpina acutifrons from the coastal waters of Alexandria, Abdel-Moati et al. (1993) recorded a C:N ratio of 7.4. Relative to Redfield et al. (1963), the C:N ratio observed in the present study, was remarkably higher than that expected for marine organisms i.e. 6.6. High $\mathrm{C}: \mathrm{N}$ ratios indicate that metabolism was oriented by lipid and / or carbohydrate synthesis rather than protein.

In marine studies, Redfield's C:N:P ratio (106:16:1 by atoms) was widely accepted as a reference (Redfield et cl., 1963); however, this ratio solely cannot give a complete (elemental) composition. Spoehr and Milner (1949) estimated biomass composition in term of proteins, carbohydrates and lipids from knowledge of the elemental composition and its relation to energy aspects. Differences in applying this ratio arise from nitrogen-free polysaccharides which are normally present as glycogen and that a small fraction of carbon may also be incorporated in the cuticle in form of $\mathrm{CaCO}_{3}$ (Spoehr and Milner, 1949).

The annual average C:P ratio of zooplankton collected from the coastal waters of Alexandria was 105.2. In summr, zooplankton was characterized by the highest $C: P$ ratios all over the localities. Such high ratios are attributed to low phosphorus contents, during this season which will also affect the N:P ratio during the same period. Zooplankton of $\mathrm{Abu-Qir}$ Bay was characterized by higher $\mathrm{C}: \mathrm{P}$ ratios, reaching 324 at El-Tabia inshore location, a value which is 3 times more than that mentioned by Redfield et al. (1963).

The N:P ratio of zooplankton fluctuated between 14.3 and 13.5 , in summer and winter respectively. Though variations between different stations in the same area do not clearly appear, the seasonal pattern in each locality seemed to show some variability. High $\mathrm{N}: \mathrm{P}$ average ratios, compared to that of Redfield et al. (1963) were observed off TPS industrial discharge i.e. 43; while off QBPS a remarkabely low ratio i.e. 6.0 was observed. The increase in N:P ratio means an increase in nitrogen over that required for balanced growth while low ratios may suggest that phosphorus is present more than required to a decreased ratio in recycled nutrients. In the present study, a statisticaly significant relationship appeared between $N: P$ ratios in both water and organisms $(r=0.8446, p<0.001)$. 


\section{REFERENCES}

abdel-Moati, M.A.R.; M.M. Atta; Khalil, A.N. and Nourel-Din, N.M. (1993). Carbon, nitrogen and phosphorus content of the copepod Euterpina acutifrons in the coastal waters of Alexandria. Bull. Nat. Inst. Ocn. \& Fish., 19: 173-190.

Aboul-Kassim, T.A.T. ( 1987 ). Cycles of carbon, nitrogen and phosphorus in the marine emvironment in Alexandria region. M. Sc. Thesis. Faculty of Science. Alexandria University, $233 \mathrm{pp}$.

Beers. J.R. (1966). Studies on the chemical composition of the major zooplankton groups in the Sargasso Sea off Bermuda. Limnol. Oceanogr., 11: 520-528.

Champalbert, G. and Kerambrun, P. (1978). Composition biochimique des copepodes de l'hypaneueston de Mediterranean Nord accidentale poids sec et analyse elementaire du carbone, de l'hydrogene et de l' azote. Mar. Biol., 45: 215-224.

Champalbert, G. and Keramburn. P. (1979). Influence du mode de conservation sur la composition chimique elementaire de Pontella mediterranea (Copepoda: Pontellidae). Mar. Biol., 51:357-360.

Comita, G.W. and Schindler, D.W. (1963). Calorific values of microcrustacea. Science, N.Y. I40: 1394-1396.

Comita, G.W.; Marshall, S.M.and Orr., A.P. (1966). On the biology of Calanus finmarchicus. XIII. Seasonal changes in weight, Calorific values and organic matter. J. Mar, Biol. Assoc. U.K., 46: 1-17.

Conover, R.J. and Corner, E.D.S.(1968). Respiration and nitrogen excretion by some marine zooplankton in relation to life cycles. J. Mar. Biol. Ass. U.K. $48: 49-75$.

Curl, H., JR., (1962). Analyses of carbon in marine plankton organisms. J. Mar. Res., 20: 181-188. 
Dortch. Q., (1982). Effect of growth conditions on accumulation of internai nitrate, ammonium, amino acids and protein in three marine diatoms. J. Exp. Mar. Biol. Ecol, 61:243-264.

Hardstedt-Romeo. M.(1982). Some aspects of the chemicill conposition of plankton from the North-Westem Mediterranean Sca. Mar. Biol. 76): 229-236

Ikeda. I., (1974). Nutritional ecology of marine sooplankton Mem. lac Hish Hokkido I/niv., 22-1-97

Kerambum. P.. (1978). Composition chimique elementaire (C.IIN) et

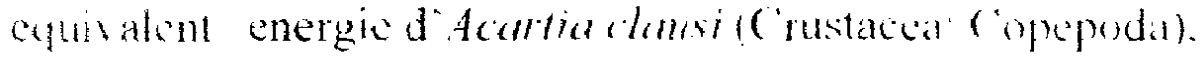
reprece mpontante dans la hiocnergetique desecoss stomes wotion de Mediterranean nordecoldentale Mar Biol. 95 115121

Murphs. I and Riley J.P.(1962). A modified single solution method for the determination of phosphate in natural waters Analytica chim. Acta. 27: 31-36.

Omori. M.. (1969). Weight and chemical composition of some important oceanic zooplankton in the North Pacific Ocean. Mar. Biol., 3:4-10.

Redfield, A.C: Ketchum,B.H.and Richards, F.A. (1963). The influence of organisms on the composition of sea water. In: M.N. Hill (ed.). "The Sea", 2 (N.Y.) :26-77.

Spoehr. H.A. and Milner, H.W. (1949). The chemical composition of Chlorella: effect of environmental conditions. Plant Physiol., 24: 120-149.

Strickland, J.D.H. and Parsons, T.R.(1972). "A practical handbook of seawater analysis". $2^{\text {nd }}$ ed. Bull. Fish. Res. Bd Canada., $167 \mathrm{pp}$.

Williams, R. and Robinsons, D.(1982). Effects of preservation on wet weight, dry weight, nitrogen and carbon contents of Calanus helgolandicus (Crustacea: Copepoda). Mar. Biol. 7l:271-281. 


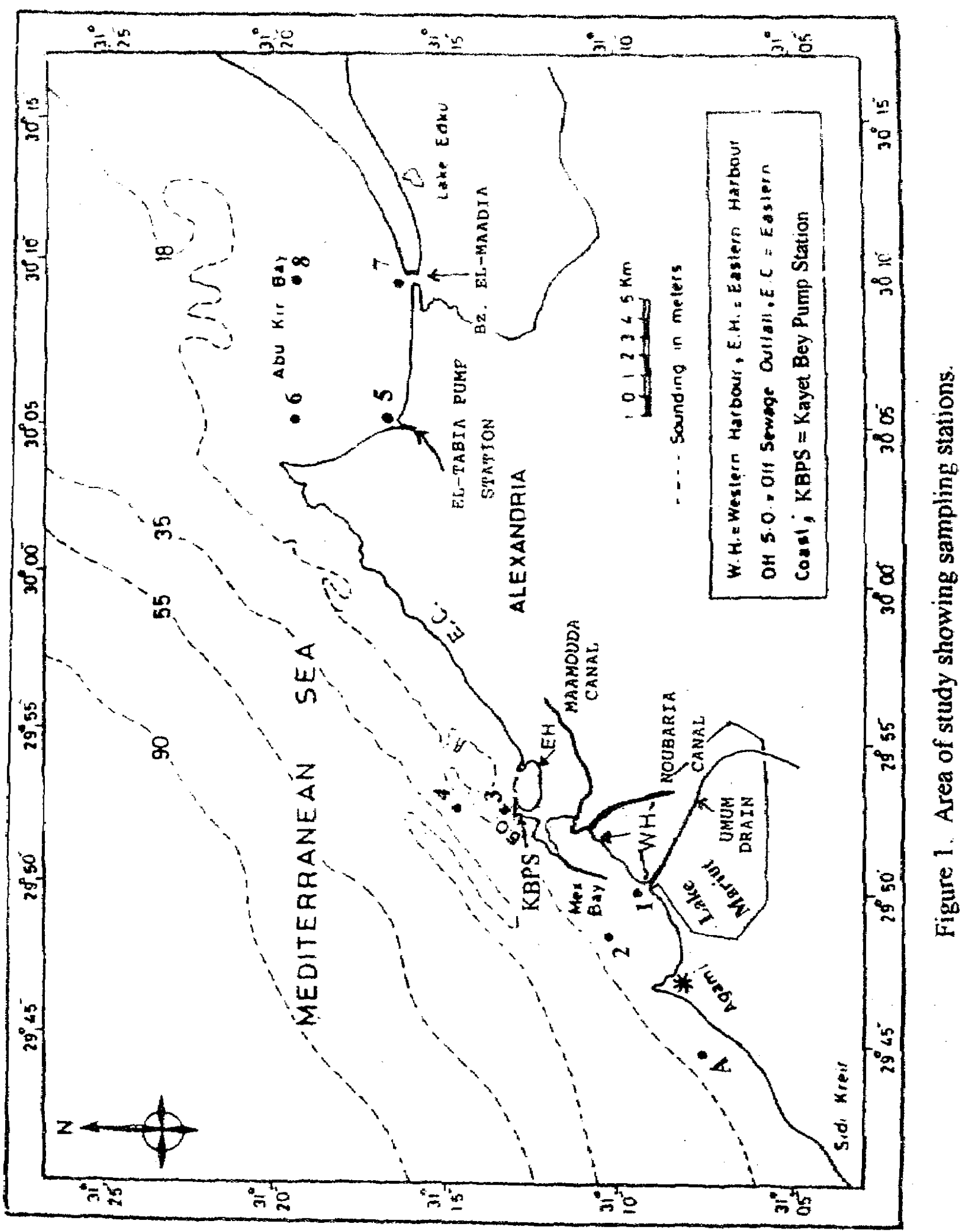



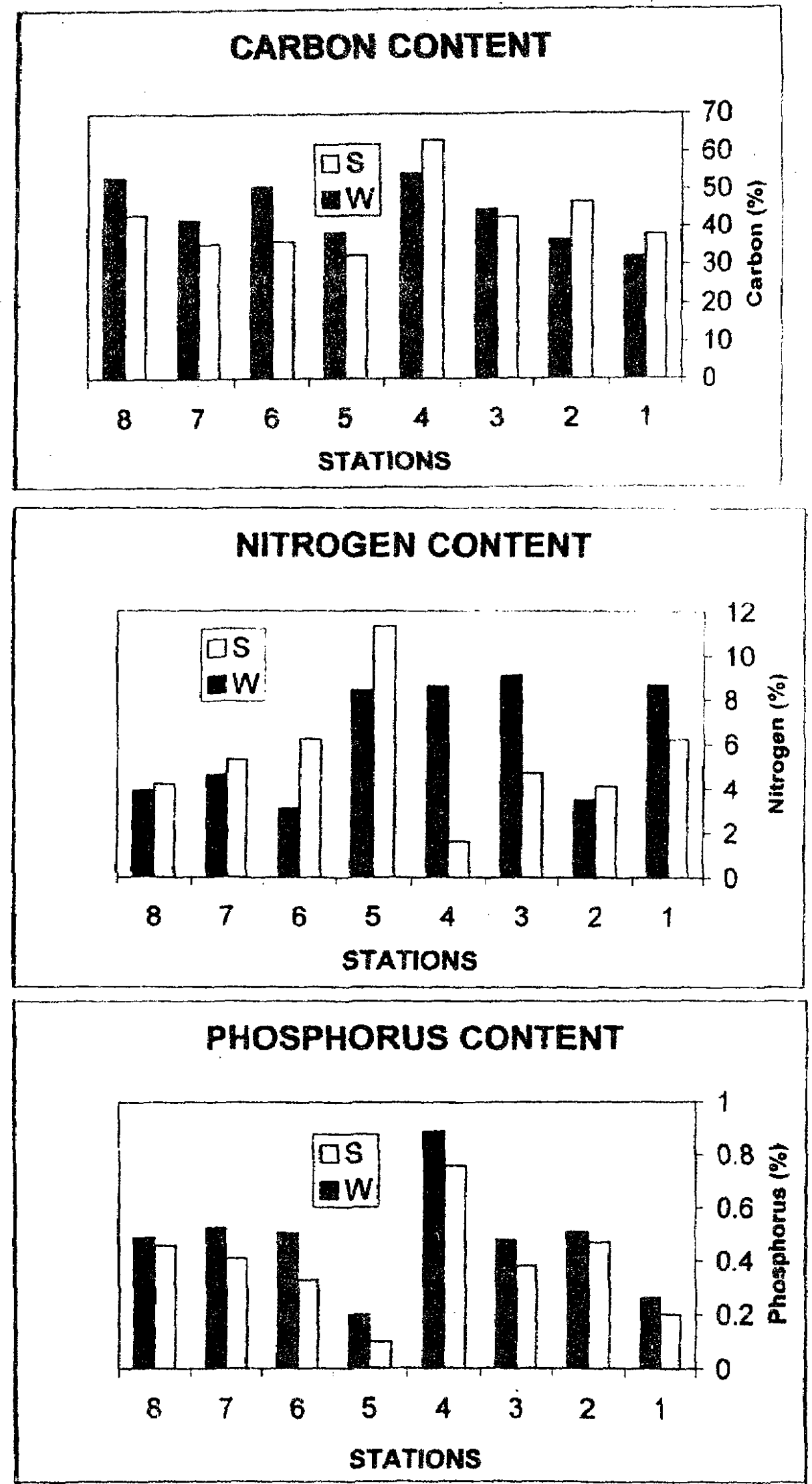

Figure 2. Carbon, zitrogen and phosphorus contents (\%) of zooplankton collected from the coastal waters of Alexandria during sunmer 1999 (S) and winter 2000 (V). 